\title{
Contending and Compromising: The Formation of Eastern Indonesian Identity During the Revolution (1945-1950)
}

\author{
Dwi Mulyatari \\ Department of History, Faculty of Humanities, Universitas Indonesia, 16424 Depok, Indonesia
}

\begin{abstract}
This study examines the process of shaping the political identity of Eastern Indonesia in 1945-1950, which was a dynamic change due to Eastern Indonesia's pluralistic character and different historical experiences. The dynamic aspects were spurred by the competition between new national identities promoted after the Proclamation of Independence on August 17, 1945, wherein pre-national identities were merged, both local and regional, that were deeply rooted in society. Interestingly, the identity issue during this period has been freely and transparently discussed in the public sphere. The issue to be addressed is to what extent local political figures played a role in establishing process of political identity in Eastern Indonesia, so that it could be incorporated into the country's historiography, which had lacked space in Indonesia's national history for more than fifty years. The sources used included the speeches of local political figures published in local newspapers and magazines during the revolution and archives of the State of East Indonesia. Using the historical method these primary sources would be examined along with secondary sources. This study argued that among the people of Eastern Indonesia, the multi-political identities - national and pre-national - could co-exist harmoniously without contesting one another. This is different from the political identity supported by the Republic of Indonesia after the Proclamation of Independence, as pre-national identity was to be eliminated since it was considered as countering Indonesian revolution. This leads to the lack of Eastern Indonesian perspectives in Indonesia

ARTICLE INFO

Article history:

Received: 28 March 2019 national historiography, particularly in the historiography of the revolution era.
\end{abstract}

Accepted: 06 April 2020

Published: 25 December 2020

DOI: https://doi.org/10.47836/pjssh.28.4.48

E-mail address:

dwi.mulyatari@ui.ac.id
Keywords: Eastern Indonesia, Indonesian historiography, political identity, revolution period 


\section{INTRODUCTION}

During the Indonesian War for Independence (1945-1950) the very idea of Indonesia became part of the struggle, both politically, diplomatically and militarily. At this time, there were two main parties involved in the conflict, spreading their influence and political control: The Republic of Indonesia (RI) and the Dutch. RI wished to extend its political control throughout the former Dutch East Indies, while the Dutch wanted to retain their political and economic influence within an independent Federal State. In other words, the competition of ideas about Indonesia became a part of the political struggle during the revolution. On one hand, RI viewed Indonesia as an independent, unitary state in which there was a strong, centralized, government system and sought to reduce Dutch influence in the society. On the other hand, the Netherlands offered a form of a federal state of Indonesia wherein the Dutch continued to exert their influence but at the same time, local people were allowed to maintain their ethnic, cultural, religious and local identity autonomously.

The Revolution was also a time when competition between national and prenational identity was a very important issue, especially in Eastern Indonesia. In this period, competition was relatively open in terms of political mobilization and freedom of expression. At this time, Indonesia was divided into sixteen states under a system of federal political government promoted by the Netherlands, one of which was the State of East Indonesia (Negara Indonesia
Timur [NIT]) covering most of Eastern Indonesia. Each state had political autonomy and sought to promote the identity of each region. This period added important elements to the discussion of how the NIT government and pro-republican groups in Eastern Indonesia championed national, regional and local identities. It is also important to analyze the extent to which there were efforts to promote the identity of Eastern Indonesia in addition to the local identities of each region. Within the federal system, it is possible for people to express their local identities parallel to regional and national ones.

During the time of 1945-1950, the development of Indonesia's national identity was challenged by the existence of prenational, regional and local identities. As far as we know, the conflict between RI and the Netherlands resulted in the recognition of the sovereignty negotiated at the Round Table Conference (Konferensi Meja Bundar [KMB]) in 1949. However, issues related to national and pre-national identity and regional autonomy were still not resolved within the KMB, but had continued to the present day to be beleaguered by regional resistance movements in Eastern Indonesia, such as the Andi Aziz rebellion (1950) in South Sulawesi, South Maluku Republic (RMS) (1950-1951) in Maluku, Kahar Muzakkar (1951-1961) in South Sulawesi and Pemerintahan Revolusioner Republik Indonesia/Perjuangan Rakyat Semesta (PRRI/Permesta) 1958-1962 in North Sulawesi (Soejono \& Leirissa, 2009). Although these rebellions were suppressed, they demonstrated at the development of 
a cohesive national identity had yet to be completed.

The 1945-1950 revolution was also an important period for understanding the dynamic competition between national and pre-national identities. It is also important to analyze how this contest was debated relatively openly in the political life of Eastern Indonesia, in which no single party was more dominant than the others, either the Dutch, the NIT government, or proRepublican forces. Competition between Indonesian, national and pre-national ideas and the struggle for political control became a part of public debate in the society of Eastern Indonesia.

There are two important concerns that make the Eastern Indonesian region appropriate for this research. First, in this region, there was a competition between two identities: national identity promoting the Republic of Indonesia, supported by proRepublican groups in Eastern Indonesia on the one hand; and strong local identity on the other. Second, in this region there was also a competition between two versions of Indonesia: the centralized Republic of Indonesia and a system of federal states, wherein each enjoyed political autonomy, of which NIT was one of the largest and most powerful federal states in Eastern Indonesia.

According to Kahin (1985), at least when compared to Java and Sumatra, the nationalists in Eastern Indonesia have fewer opportunities in realizing an independent political position after the Japanese occupation. This was due to the strength of the Australian military that in a short time had occupied much of Eastern Indonesia and facilitated the re-establishment of the Dutch administration. Moreover, as Kahin (1985) argued, the history of the revolutionary period in Indonesia tended to be generalized and only reflected the perspective and attention of the national government alone. In other words, that lens opened an opportunity to write an assessment of Indonesia's struggle for independence from a regional point of view.

The nation-building agenda during the reign of Sukarno and Suharto attempted to minimize and set aside discussions relating to pre-national identity issues and regional differences, both in public discussion and in official national/government history. Sukarno (1945-1965) strongly promoted Indonesian unity starting from the Proclamation of Independence. Sukarno was convinced that the revolution had not been completed until the entire territory of the former Dutch Indies was under the control of the Indonesian Nation. This effort was followed by Suharto (1966-1998) by applying Suku, Agama dan Ras (SARA) i.e., ethnic, religious and race policies, which prohibited discussion of sensitive ethnic, religious and racial issues. Both Sukarno and Suharto used military force to control the insurgencies and other forms of resistance. After Suharto's rule, SARA's policies had been maintained, although some taboos may, at least, be more openly discussed, such as religious issue that was not used as a political term. Indonesia's political system became more open to discussions related to decentralization and local autonomy policies, which had 
grown tremendously since 1999, while the discussion of sub-national identity remained limited by the government, if not completely closed. By considering the background and the context discussed above, the main issue to be discussed was, to what extent did local political figures play a role in establishing a political identity in Eastern Indonesia. The central argument of this study was that among the people of Eastern Indonesia, multi-political identity, both national and pre-national, could be maintained together without opposing one another. This is different from national identity championed by the Republic of Indonesia after the Proclamation of Independence, which was to eliminate the pre-national identities that were considered as opposing the Indonesian revolution.

\section{MATERIALS AND METHODS}

The approach for this research is qualitative in nature, pursued by critically using a wide range of primary and secondary historical sources, such as the NIT archives, local newspapers, the Dutch intelligence reports as well as relevant books, which had been less frequently used in mainstream national historiography. Hopefully, the internal point of view of the local political leaders may be derived from these kinds of sources to balance the Republic of Indonesia's government's point of view as generally reflected in national Indonesian historiography.

The research method used was historical, through four stages. The heuristic stage was used to collect relevant historical sources. This collection stage was based on a wide range of Dutch archives and Indonesian local newspapers as primary sources, while the secondary sources were derived from books and journals. The primary sources were mainly the material of Indonesian origin from that period (1945-1950). For instance, the Archives of Government of East Indonesia in Makassar; Notulen (Hansard) and speeches of the East Indonesian Parliament and regional councils; local newspapers and magazines, which contained not only news and articles on political issues but also stories, opinions and interpretations of Indonesians reflecting upon their experiences during the period.

In the criticism stage, the diverse range of primary and secondary sources were examined critically and skeptically. By having regard for the position, political and institutional interests of the writer, as well as the potential readers of both government and public documents, the data would be interpreted into useful facts that could support the paper. In the interpretation stage, all the selected data were verified and interpreted to develop facts to support the case that should be constructed logically and objectively. The last stage is historiography where the facts were reconstructed into an analytical and systematic writing.

\section{RESULT AND DISCUSSION}

\section{National and Pre-National Identities}

In the period of the Indonesian struggle for independence, political identity was always associated with a political struggle (Soejono \& Leirissa, 2009). After August 
17, 1945, Indonesia's national identity — as a new national political identity-grew and developed through physical, diplomatic and political struggles. The existence of RI with its supporters in Eastern Indonesia, the formation of NIT and the presence of local political elements that were still very strong and real, shows that the formation of political identity in Eastern Indonesia involved some competition for political identity, both national and pre-national. Most of the political struggles in the region were packaged within the framework of an identity contestation, promoted by each group, namely the pro-Indonesian republican group, the federalist group, and local elites. Each competing group strove to promote their respective political identity to the people of Eastern Indonesia and to mobilize support for their political agenda. Although Eastern Indonesian area was not the center of the Indonesian independence movement, in almost all of its areas there were political groups favoring Indonesian independence. During the period of the War for Independence, the administration of the Eastern Indonesia region took the form of the federal government. Nevertheless, local political organizations in the region were still very strong in competing for power, both against the power of the RI government and the power of the Dutchformed government.

For Indonesia, national identity can be said to be a relatively new concept, when compared with local cultural, religious and ethnic identities. According to Elson (2008), there is no Indonesia before the twentieth century, either as an idea or as a territory. However, localism had already existed as an important key in political and cultural identity in Indonesia. Communities in Indonesia had a long history of the times of empires and sultanates and other political structures before the formation of colonial rule. Although the idea of Indonesia grew slowly after the turn of the twentieth century, Indonesia was successfully proclaimed to be a unified nation on August 17, 1945. Sukarno and Mohammad Hatta, who proclaimed Indonesian Independence, sought to unite the population of the Indonesian archipelago as a new nation. They sought to realize the national idea based on the differences of ethnic groups, languages, religions and cultures that already existed in Indonesia. This nation-building effort was continued by later presidential efforts.

According to Henley (1996), although some "dreamers" of the concept of Indonesia are not from Eastern Indonesia and in this region, there are a few branches of nationalist organizations before World War II, but Minahasa is an exception. The educated leaders of Minahasans managed to build and envision the concept of Minahasan nationalism within the larger framework of Indonesia. Henley (1996) stated that during the colonial period, regional nationalism was conditioned by the Dutch colonial experience and retained, although some of the Minahasans thought they were Indonesians. In the pre-war Minahasa case, the concept of regional nationalism did not conflict with the development of the Indonesian national idea (Henley, 1996). 
He further argued that, in essence, naturally, these regions were relatively immeasurable when compared to the territory of the nation. This provided an opportunity for these regions to attain a certain quality of dynamism and flexibility that might take on a form of territorial patriotism and generated a regional political phenomenon.

The two identities, Indonesian national identity and NIT regional identity, both acknowledged ethnic, cultural, and religious diversity as Indonesia possesses rich cultural, ethnic, and religious diversity. The diversity is even greater compared to western parts of Indonesia. The similarity is today known as "Bhinneka Tunggal Ika" (Unity in Diversity). What significantly distinguishes the two is when identity is used in political terminology. The national identity supported by pro-Republican groups is unitarian as a form of state administration. However, the regional identity supported by pro-federal groups is the federal state. In a unitary state, the role of central government is very dominant. On the other hand, in the federal system, each Zelfbestuur region (self-local government/ kingdom) has considerable sovereignty while still supporting the federal-state system and does not mind being in it.

\section{Promoting National Identity}

At the end of the Japanese occupation of Indonesia, an investigative committee was established to prepare for Indonesian independence (Badan Penyelidikan Usaha Persiapan Kemerdekaan Indonesia [BPUPKI]), having been announced by the Japanese in March 1945. The leaders of Java became its members, who then reached an agreement for a new constitution in which Indonesia was designated as the Republic of Unity. Shortly before its independence, a new preparatory committee for independence was announced. Ratulangi and other representatives of the outer islands then became members. This committee had a function to proclaim the existence of a new Indonesian state (Schefold, 1995). The notion that the defeat of the Japanese by the Allies on August 15, 1945, led to a new Indonesian state supported by Japan, but it has no factual basis. Instead, prominent Indonesian figures gathered in Jakarta, took the initiative to declare Indonesia's independence on August 17, 1945.

The involvement of Eastern Indonesian representatives in Panitia Persiapan Kemerdekaan Indonesia (PPKI, which was the crucial committee replacing BPUPKI) in representing the interests of Eastern Indonesia was very important in the preparation for Indonesian Independence. The presence of Sam Ratulangi, who was appointed by the Republic of Indonesia as the governor of Sulawesi after the proclamation in Makassar, did not last long. This change was due to the Dutch Linggajati Agreement (NICA), which was considered legitimate outside of Java, Madura and Sumatra. The arrival of Australian troops on behalf of the Allies in Makassar was exploited by the Dutch to re-establish their power and administration in the region. In April 1946, Ratulangi and six members of the Partai Nasional Indonesia (PNI), who were members of the pro-Republican 
group, were captured by the Dutch and exiled to Serui (Papua) until August 3, 1948 (Ministry of Information of The Republic of Indonesia, 1953). However, before they were arrested, Governor Ratulangi, the pro-Republican group in Sulawesi, used the opportunity to spread and campaign for the idea of the Republic of Indonesia throughout Sulawesi Island, particularly in Makassar and Minahasa, and to mobilize community support for the new republic. The formation of the People's Service of IndonesianSulawesi (Kebaktian Rakjat Indonesia Sulawesi [KRIS]) and the People's Security Force of Sulawesi (Pasukan Keamanan Rakjat Sulawesi [PKRS]) by pro-Republican organizations encouraged young people to resist the Dutch government's propaganda on the federal administrative system for Eastern Indonesia. One example of the Ratulangi campaign was depicted in his letter to the Minahasans while he was in Makassar. The letter was brought by a courier, Miss W. B. Politon, and then read in a meeting to announce the formation of Indonesian Youth Association (Perhimpunan Indonesia Muda [PIM]). The letter stated that Ratulangi called on the Minahasa people to avoid thinking about the province and that the people should unite in fighting for Indonesian independence as it did in Java. One of Ratulangi's statements to encourage people, especially the Minahasans, to defend the republic was to call themselves "Indonesians and not Minahasans" (Wowor, 1977).

Other efforts of local figures to build a national identity in Eastern Indonesia were conducted by I. H. Doko and H.
A. Koroh Raja of Amarasi, Timor. At a meeting in Malino, Doko and Koroh were sent by Partai Demokrasi IndonesiaTimor (PDI-Timor) as Timorese-nationalist representatives. In the meeting of Malino and Denpasar, Doko demanded the right of self-determination (zelfbeschikkingsrechts) for the whole of Indonesia. He argued that regarding the format of Indonesia's future, be it a federation or a unitary state, Timor's representatives must leave the final decision to Sukarno and Hatta (Agung, 1993; Doko, 1981). As a temporary NIT member of parliament, Doko was affiliated with the National faction as the secretary. The faction aimed at sovereignty and independence in the Republik Indonesia Serikat (RIS). Based on his experience during the Japanese occupation, which indirectly promoted "Nationalism" within the framework of "Asia for Asia" and his political role in the early revolution in Java, the origins of Doko's nationalist sentiment were quite clear.

\section{Regionalism as an Option}

Similar to national identity, the development of regional identity in Eastern Indonesia was also relatively new. According to Chauvel (1996) de Groote Oost (the Great East), a new autonomous administrative unit in Eastern Indonesia, was formed by the Dutch in 1938 to support trade by promoting efficient governance. This act was likely to be sustainable with the formation of NIT (a.k.a. the State of East Indonesia) in the form of a federal government in 1946. However, there were rational differences 
underlying the formation of the two regional entities. NIT was established as a Dutch strategy in loading its political authority and influenced onto the territory of RI on August $17^{\text {th }}, 1945$, so that the Dutch were able to rerun their control in Eastern Indonesia. Meanwhile, de Groote Oost (the Great East) was formed as part of the Dutch administrative reform effort on the islands outside of Java.

The Denpasar Conference of 1946, which resulted in the creation of NIT in early 1947, offered a new regional identity as a state. However, the body of NIT still showed its dominant local identity and thus wanted to be maintained by its supporters within the NIT federal framework. This fact was evident from the hearing before the Denpasar Conference. The conference participants supported at least two different political aspirations, pro-Federal groups and pro-Republicans. Nadjamoedin Daeng Malewa, a representative from South Sulawesi, and Anak Agung Gde Agung from Bali, for example, represented the proFederalist position. Meanwhile, Tadjoeddin Noor from South Sulawesi and I. H. Doko from Timor supported the Republic. In addition, the interests of local and regional groups seem to be a strong choice. This was evident from the aspirations articulated by this elite political group, presented through their speeches (Van Goudoever, 1947). Prominent local leaders tried to accommodate local interests within the NIT governance structure. During the Denpasar Conference, local political elites in Eastern Indonesia wanted to respond to political change at national and international levels. Almost all parts of Eastern Indonesia were fully represented at the Denpasar Conference. However, the presence of local political elites at the conference might be considered to have represented groups deemed "agreed" with the formation of NIT - as planned by van Mook as the purpose of the conference.

Although, in general, the representatives of the special district at the Denpasar Conference could also have been divided into pro-Republican and pro-Federal categories, it should be noted that pro-Republican groups could be said to be relatively willing to cooperate with the Dutch federal idea, as evidenced by their willingness to be present at a conference whose idea was promoted by van Mook. This idea was reinforced by their later participation in the NIT cabinet.

On the other hand, the pro-Federal group at the conference was then willing to support the Republic and refused to cooperate with Beel's plans for a transitional government under an Indonesian-Dutch Union, after the Dutch launched its second military action against the RI in December 1948. Nadjamoedin Daeng Malewa, a local leader from South Sulawesi, was one of the examples of the pro-Federal group. As a member of the South Celebes Council, he was appointed to represent South Sulawesi at the Malino and Denpasar Conferences (Penjoeloeh Bali, 21 March 1947). Nadjamoedin was very enthusiastic about the concept of a federal state, a feeling which he expressed in his speech at the Denpasar Conference. Although this 
concept did not involve secession from Indonesia, from his point of view the Federal State was the most appropriate form for the future of the people in South Sulawesi and for other Indonesians. He believed that a country of thousands of isolated islands should be managed by recognizing the diversity of all ethnic groups, especially in Eastern Indonesia. He argued that with the form of federal administration, the interests of each region would be assured. This sentiment was conveyed during his speech at the Denpasar Conference (General Government Commissariat for Borneo and the Great East, 1946) wherein the idea was later repeated at the first meeting of the NIT Parliament on April 22, 1947. Nadjamoedin ("Pidato P.J.M. Nadjamoedin... (Part 1)", 1947) said that:

[Translation: ....as a result of this geographical condition-our country is inhabited by those groups of diversified residents...in addition, for those who pay attention, there are so many religions in the country, they are certainly aware, that a country like this cannot be formed based on common similarities like it can in Java, for example...then, because it consists of several areas, it should be established on the basis of a federation and because of that the autonomy of these areas must be held in high respect. With that format of the state, the progress of each region can be guaranteed according to its nature and their own needs...We are a nation despite of having the same feelings, but we also have a great desire to pursue our own needs. No Balinese wants to be ruled by the ideologies of the Minahasa, no Makassarese would submit to the Ambonese' notions, and vice versa. However, if each person saw that his authority was already guaranteed in their own backyard, the people of East Indonesia would shake hands with one another to work together in such a state...]. ("Pidato P.J.M. Nadjamoedin... (Part 1)”, 1947).

Nadjamoedin's commentary reflected his view that different ethnic and religious groups needed to feel that they were wellrecognized in their respective political units because of the differences between the two sides. From his experience, he felt that any group like the Minahasans or the Balinese needed to have the most appropriate degree of autonomy within the federal system rather than reached a compromise on a set of agreed-upon principles for the whole of the proposed Republic. Our country in this speech referring to NIT and Nadjamoedin seemed to describe the centralized structure of NIT, of which thirteen regions had considerable autonomy. Through the character of Nadjamoedin we can see two identities that must be developed at once, namely strong local identity and the demands of the federal government that guarantee each local area its autonomy.

Participants of the Denpasar Conference then chose Nadjamoedin Daeng Malewa for the position of Prime Minister of 
the first NIT and, concurrently, Minister of Economics. He conveyed a political manifesto that suggested that the federal state system was the best solution for Indonesia. He came to this view based on his evaluation that various regions of Indonesia had improved economically through the application of centralized state structures applied by the Dutch since the beginning of the twentieth century. The great distances between central and regional governments significantly influenced the amount of power that could be delegated to the regions. He believed that the advantages of federal constitutional systems such as Canada, the United States and Australia were abundant. He argued that the federal state was a must to realize the ideals of a country's independence. Nadjamoedin argued that a stronger and more prosperous state would not have inequalities applied others. Accordingly, equality would be created not only in economics but also in culture, finance and law ("Pidato P.J.M. Nadjamoedin... (Part 2)", 1947).

Similarly, Anak Agung seriously considered the importance of maintaining the existence of zelfbestuurder (self-local government leader/Raja) in a modern and democratic NIT format. As one of the traditional elites who ruled Bali's Gianyar Kingdom, he realized that the King's traditional power rights would be reduced in the new format of Eastern Indonesia under NIT. Therefore, as his speech at the Denpasar Conference mentioned that by giving the mandate given by Paruman Agung, Anak Agung emphasized the important fact that
$75 \%$ of Eastern Indonesians were governed by the traditional Swapraja government under zelfbestuurder (self-local government leader/Raja) and their existence should be accommodated within the NIT (General Government Commissariat for Borneo and the Great East, 1946). In other words, Anak Agung agreed to develop a federative idea for Eastern Indonesia.

As a representative of South Sulawesi in the Denpasar Conference, Tadjoeddin Noor ("Sidang Parlement", 1947) had a different political view from Nadjamoedin Daeng Malewa. He clearly supported the concept of a unitary state, and was thus pro-republic. He supported the Linggajati Agreement as a formula for the establishment of the RIS by arguing that NIT should be granted political rights at least until the establishment of RIS and, together with RI, NIT became a state component in Indonesia. He expressed his opinion in his speech while leading the NIT Parliament.

Although Tadjoeddin ("Sidang Parlement", 1947) claimed that a sovereign RIS was important and should be established soon, at least on January 1, 1949, he also believed that a sovereign NIT must be secured within the RIS. Tadjoeddin argued that the format of bondstaat (federation state) was better perceived to formulate a sovereign RIS than the statenbond (Unitarian state) format because in the bondstaat (federation state) format every state is unitary and has no sovereign rights, since the central and state governments would divide the authority. Meanwhile, in a statenbond (Unitarian state), several 
sovereign states agree to work together to safeguard mutual interests. In other words, every state of the federation of this type has sovereignty over its territory.

\section{Localism as the Third Layer of Identity}

The strength of the existence of local identity in Indonesian society must not be ignored during the development process of national and regional identity in the region. Old and strongly rooted local identity in the community is closely related to ethnicity, culture, and religion. This fact means that the development of a national identity varies greatly according to region. Local identities and political entities in Indonesia developed long before the Portuguese and Dutch came to Indonesia. For example, the Kingdom of Gowa in South Sulawesi, the Hindu Kingdoms of Bali, the Sultanate of Ternate and Tidore in Maluku. Even a completely new Bali administration was incorporated into the administration of the Dutch East Indies relatively early in the twentieth century compared to other regions of Eastern Indonesia that had been integrated first.

After the Denpasar Conference, the founding of the NIT (i.e., the State of East Indonesia) became a reality in December 1946. Internally, the NIT government implemented a democratic and modern government with the utmost promotion of educated government officials and policies convincing traditional elites to follow the will of the government. Modern and democratic governments were needed to prepare the NIT as part of the future RIS.
However, there were concerns among traditional elites that their traditional rights over the territories would no longer be guaranteed under the administration of the RIS, whereas NIT would become a part of it. In connection with the effort to preserve their autonomy in their territory, the eighteen eastern kingdoms of Indonesia held a meeting in Malino, South Sulawesi in May 1948. It had been known as the Second Malino Meeting ("Senaat Sementara", 1949). Local traditional elites feared that their authority over their territory could not be maintained if the NIT had planned to modernize the government. They intensively discussed their political position if the NIT were to have become a part of the RIS.

Although the concept of a federal system for a new country in Eastern Indonesia was well-prepared by van Mook long before the meeting in Denpasar, it was undeniable that local identity, as a political aspiration, was widespread during the conference. The majority of regional representatives used the meeting to convey their aspirations about their respective regional autonomy through their speeches, arguing that regional autonomy is the people's right. This was stated among others by Katoppo and Wenas, representatives of Minahasa. Although both agreed with the idea of "The NetherlandsIndonesia Union," the self-determination of each region remained an important focus for the Minahasa representatives. Katoppo, in his speech, mentioned that the new status of the State of East Indonesia (NIT) had become strong inside and outside the country. However, he believed that 
inter-state power, especially between the Republic of Indonesia and the State of East Indonesia, should be applied equally. He also referred to Article 6 of the draft regulation that the respective determination of each region would be guaranteed by the state system of NIT. Meanwhile, Wenas wanted the State of East Indonesia to be composed of dozens of self-governing small kingdoms (zelfbesturende rijkjes) that directly controlled their territory and would strengthen the group within the state (General Government Commissariat for Borneo and the Great East, 1946).

\section{Compromise Supplies the Solution}

A key turning point occurred when the Dutch launched their second military aggression against the RI in December 1948. As a result, the capital of Yogyakarta was occupied by Dutch troops and the leaders of the Republic were arrested and exiled to Bangka. This aggression disappointed NIT leaders. On the one hand, the Dutch treatment of Republican leaders, especially Sukarno and Hatta, was deemed inappropriate and military action was seen as Dutch intervention against Indonesian sovereignty. On the other hand, Indonesia's reluctance to resolve diplomatic political relations with the Dutch resulted in a protracted negotiation process and did not reach the solution expected by both RI and the Netherlands. Dutch military action became the most obvious of changes in the political thinking of modern local leaders within NIT. Their views were different from the Denpasar Conference where local perspectives seemed to be very common.
After the second Dutch military aggression and when the objectives of negotiations between Indonesia and the Netherlands became clearer about the formation of the RIS, The political identity developed by modern, educated local leaders seemed to be more nationalistic.

To resolve the conflict, RI and the Netherlands then agreed to achieve the best diplomatic solution by holding a Round Table Conference (Konferensi Meja Bundar [KMB]), which proceeded in August 1949 and was then signed in November 1949. International criticism and pressure on the Netherlands brought on the NICA, meaning that the Netherlands would not be staying long in Eastern Indonesia. That is, the Netherlands would leave Indonesia and Indonesian sovereignty would be recognized and transferred to RIS. This national political situation had an impact on changing the political thinking of the Eastern leaders of Indonesia to be in line with the political opportunities offered to them, especially, for those who were experienced in modern higher education and were involved in the administration of NIT compared to those who had been known as a traditional elite group. The concept of regional identity of this group was becoming more nationalistic. This local group of leaders came to a new understanding that the Dutch would not resolve its problem with the Republic of Indonesia (RI) diplomatically. In addition, this military action brought international attention to the internal political situation in Indonesia that had brought de facto support and recognition to the RI. 
This situation urged the NIT leaders to consider that the main agenda at that time was to work together with RI, to unite Indonesians under the RIS. This was demonstrated in leaders' speeches on numerous occasions mentioned in several local newspapers and magazines, such as Negara Baroe (Makassar), Penjoeloeh (Bali), and Pandji Negara (Makassar) during 1945-1949. One of them was Anak Agung, who held his position as the Prime Minister of NIT. He promoted a synthesis policy as a political agenda of the NIT in international relations during preparation of KMB. Negotiations with both RI and the Netherlands benefited NIT. His political strategy was presented in his speech at Radio Makassar on February 23, 1949. Anak Agung ("Menudju Republik N.I.S.", 1949) was said that:

[Translation: ... Part III and the conclusion of the speech stated once again that the politics adopted by NIT that were to search for synthesis in all directions in the community, both toward the Netherlands and toward Indonesia, in the nation itself...This policy was used out of conviction that the life of the nation cannot and should no longer be seen as "between us alone." Inevitably, because of historical progress, it must also consider its relationship with the Netherlands. Therefore, including the absolute conditions of working together with the Dutch; however, it was not because of them that the interest of the nation itself was undeveloped!] ("Menudju

Republik N.I.S.”, 1949, p. 2)

Anak Agung, as the Prime Minister, was keen to take an important role in the KMB to convey the political interests of NIT and reposition its political role after the second Dutch military aggression. This enabled Anak Agung to play an active role by forming the Federal Consultation Meeting (Bijeenkomst Federaal Overleg [BFO]), conducting an inter-Indonesia conference with his synthesis policy, and negotiating with Sukarno-Hatta in Bangka. Thus, it may be said that NIT, with Anak Agung as Prime Minister at the time, developed more national identity than ever before, with the aim of preparing an understanding with RI in facing the round table conference.

\section{CONCLUSIONS}

The formation of Eastern Indonesia's political identity had developed through a process of negotiation and compromise through local political figures, having adapted to political changes and political needs in the region. The process of its formation came with competitions between national, regional and local identities that were deeply rooted in local communities.

The identity that was then used and developed was not something that was "black and white" (and thus static) but rather dynamic in nature and having flexibility in accordance with the political developments that occurred. Thus, the identity of East Indonesian politics is not necessarily depicted by one identity alone, but instead 
has three layers of identity in which each tier can be more dominant than the others at any one time, depending on the political situation and the desired interest.

During the peak period of the establishment of the NIT, Eastern Indonesia's cultural, ethnic, and religious identity could be harmonized through federal state policies. They offered a bigger opportunity for local/ regional political interests and allow each region's identity and personality to develop. This compromise was offered as NIT also needed political support from these local elites. As long as regional interests can be accommodated by NIT, the harmony could be maintained. The situation changed when the Round Table Conference (Konferensi Meja Bundar [KMB]) in December 1949 resulted in an agreement that the Dutch recognized Indonesian sovereignty by the establishment of the Federal Republic of Indonesia, the Republic of the United States of Indonesia (Republik Indonesia Serikat [RIS]), in January 1950, and NIT was one of the states of RIS. To integrate regional identity within a national framework, Prime Minister Anak Agung made a compromise through an integrated policy, known as Synthesis. Synthesis policy had been slowly implemented since Anak Agung became the Prime Minister of NIT for 2 periods, from 15 December 1947 to 27 December 1949. Since the establishment of RIS, in which Anak Agung was appointed as Interior Minister in RIS Cabinet, the synthesis policy had been implemented by the NIT within RIS framework. NIT political policy was aimed more at the alignment of the NIT and RIS government relationship rather than the NIT and the local powers in Eastern Indonesia. This led to the disappointment of the local elites, especially the pro-federal groups that carry regional and local identities. However, the harmonization was restored after the president of RIS, Sukarno, politically approached the local elites of Eastern Indonesia. Meetings were conducted with the Kings of different areas in Eastern Indonesia that eventually gained support towards RIS.

The connection with the historiography of the revolutionary period in Indonesia, with a deeper understanding of this multi-identity of Eastern Indonesian politics, as developed by local leaders, is expected to open up opportunities for franker, open discussion. In addition, despite the many important writings pertaining to the revolution in Indonesia, there has been a lack of attention to discuss the dynamics of political identity among local political leaders in Eastern Indonesia. Hopefully, this research sufficed to satisfy the deficiency.

\section{ACKNOWLEDGEMENTS}

The study was supported by a grant from the Final Research Indexed International Publication Grant Program (PITTA) Universitas Indonesia.

\section{REFERENCES}

Agung, I. A. A. G. (1993). Kenangan masa lampau: Zaman Kolonial Hindia Belanda dan Zaman Pendudukan Jepang di Bali [Memories of the past: Bali in Dutch East Indies and Japanese Occupation era]. Jakarta, Indonesia: Yayasan Obor Indonesia. 
Algemeen Regeeringscommissariaat voor Borneo en de Groote Oost [General Government Commissariat for Borneo and the Great East]. (1946). De Conferentie te Denpasar 7-24 December 1946 [The Denpasar Conference 7-24 December 1946]. Batavia, The Netherlands: G. Kolff \& Co. Batavia.

Chauvel, R. H. (1996). Beyond the Wallace Line. In C. Barlow and J. Hardjono (Eds.), Indonesia Assessment 1995: Development in Eastern Indonesia. Canberra, Australia: Jointly Institute of Southeast Asian studies, NUS, Singapore and Research School of Pacific and Asian Studies, ANU.

Doko, I. H. (1981). Perjuangan kemerdekaan Indonesia di Nusa Tenggara Timur [The Indonesian independence struggle in East Nusa Tenggara]. Jakarta, Indonesia: PN Balai Pustaka.

Elson, R. E. (2008). The idea of Indonesia: A history. Cambridge, England: Cambridge University Press.

Henley, D. E. F. (1996), Nationalism and regionalism in a Colonial Context: Minahasa in the Dutch East Indies. Leiden, The Netherlands: KITLV.

Kahin, A. R. (Ed.). (1985). Regional dynamics of the Indonesian Revolution: Unity from Diversity. Honolulu, Indonesia: University of Hawaii Press.

Menudju Republik N.I.S. (1949, February 28). Pandji Negara, p. 2.

Ministry of Information of The Republic of Indonesia. (1953). Republik Indonesia: Propinsi Sulawesi [The Republic of Indonesia: Sulawesi Province]. Djakarta, Indonesia: Kementerian penerangan Republik Indonesia.

Pidato P.J.M. Nadjamoedin daeng Malewa Perdana Menteri [Speech of Prime Minister P.J.M.
Nadjamoedin daeng Malewa Perdana Menteri] (Part 1) (1947, April 23). Negara Baroe, p. 2.

Pidato P.J.M. Nadjamoedin daeng Malewa Perdana Menteri [Speech of Prime Minister P.J.M. Nadjamoedin daeng Malewa Perdana Menteri] (Part 2) (1947, April 24). Negara Baroe, p. 1.

Senaat Sementara. (1949, June 15). Pandji Negara, p. 6 .

Schefold, R. (Ed.). (1995) Minahasa past and present: Tradition and transition in an outer island region of Indonesia. Leiden, Netherlands: Research School CNWS.

Sidang Parlement Negara Indonesia Timoer jang pertama [The First Eastern Indonesian State Parliament Session] (1947, April 23). Negara Baroe. p. 1.

Soejono, R. P., \& Leirissa, R. Z. (Eds.). (2009). Sejarah Nasional Indonesia Jilid VI, Edisi Pemutakhiran [National history of Indonesia, (Vol. VI, Revised ed.)]. Jakarta, Indonesia: Balai Pustaka.

Van Goudoever, W. A. (1947). Denpasar Bouwt een Huis [Denpasar builds a house], Een Overzichtelijke Bewerking van Notulen en Tekstueele Redevoeringen ter Conferentie van Denpasar 7-24 December 1947. BataviaCentrum, The Netherlands East Indies: Regeerings Voorlichtings Dienst (RVD).

Wowor, B. (1977). Sulawesi Utara Bergolak: Peristiwa Patriotik 14 Februari 1946 dalam Rangka Revolusi Bangsa Indonesia [Revolution in North Sulawesi: Patriotic Rebellion February 14, 1946 in the Indonesian National Revolution). Jakarta, Indonesia: Badan Penerbit Alda. 
